\title{
DAKWAH DAN PEMBERDAYAAN MASYARAKAT
}

\author{
Masrial \\ Universitas Islam Negeri Imam Bonjol Padang \\ Email: masrial@uinib.ac.id
}

\begin{abstract}
This paper aims to describe the role of transformative da'wah in community empowerment. This is library research type by gathering various references related to da'wah. The results of the analysis shows that for the eradication of crime, that is human stupidity of all forms, in the form of kufr, polytheism, demoralization, poverty and dehumanization carried out by the method of preaching, both in the form of oral, written, and deed. Da'wah must not neglect the fulfillment of human needs as the object of da'wah consisting of material or material, spiritual or psychological dimensions, and social or social aspects.
\end{abstract}

Key Words: Preaching, community empowerment

\section{PENDAHULUAN}

Secara cammencensepemahaman dakwah yang berkembang di masyarakat awam, adalah kegiatan penyampaian pesan-pesan ajaran al-Qur'andan Sunnah melalui kegiatan ceramah, khutbah atau wirid pengajian.Maka setiap kegiatan dakwah yang dilkukan keterlibatan muballig menjadi posisi kunci. Pemaknanaan dakwah dalam terminology micro yang seperti ini sesungguhnya belum bisa menyelesaikan persoalanpersoalan umat, akan tatapi hanya bisa menjamah wilayah pinggir kehidupanmasyarakat.

Secara filosofis dakwah sesungguhnya adalah segala rekayasa dan rekadaya untuk mengubah segala bentuk penyembahan kepada selain Allah menuju keyakinan tauhid, mengubah semua jenis kehidupan yang tidak Islami kepada system kehidupan yangIslami untuk memperoleh kebahagian lahir batin dunia dan akhirat (Hakim, 2016; Syamsuddin \& Ag, 2016; Yasiroh, 2016). Format lain dalam terminology akademisnya dakwah secara macro dapat dimaknai social reconstruction (rekonstruksi sosial). Menurut istilah Amien Rais "rekonstruksi masyarakat yang multidimensional'.

Hasan al-Bana menyatakan dakwah adalah identik dengan Islam itu sendiri yang mengandung makna yang luas (Hidayat, 2013; Ismail \& Hotman, 2013; Riyadi, 2014). Dengan demikian figur da'i dapat dilakukan oleh berbagai ragam profesi dan keahlian sesuai dengan kebutuhan manusia itu sendiri (Shobron, Rosyadi, \& Suaidy, 2016). Pada dasarnya dakwah merupakan ajaran agama yang ditujukan sebagai rahmatan lil a'lamin (Fatmawati, 2018; Thoyyib, Fahmi, \& Si, 2018; Zainudin, 2009). Ada dua sisi dakwah yang tidak dapat dipisahkan, tetapi dapat dibedakan, yaitu menyangkut isi dan bentuk, subtansi dan format, pesan dan cara penyampaian, esensi dan metode (Aini, 2018; Akmal \& ACEH, 2017; Utami, n.d.). Subtansi mempunyai dimensi universal yang tidak terikat oleh ruang dan waktu, sedangkan format atau cara penyampaian dapat berbeda-beda 
menurut ruang dan waktu (Restendy, 2017; Safei, 2016).

Dakwah adalah aktivitas menciptakan perubahan sosial dan pribadi secara kultural yang didasarkan pada tingkah laku pembaharunya (Hasanah, 2014). Maka yang menajdi inti dari dakwah itu adalah terjadinya perubahan, perbaikan dan pembaharuan pada diri individu, keluarga dan masyarakat dari kondisi yang tidak baik menjadi lebih baik sesuai dengan tuntutan ajaran Ilahiyah (Hikmawati, 2016).Tren sederhana dapat dikatakan dakwah suatu proses internalisasi, transmisi, difusi, institusionalisasi dan transformsi Islam yang melibatkan da'i, mad'u, materi, metode, media, ruang dan waktu untuk mewujudkan kebahagian di dunia dan di akhirat (Budiantoro, 2017; Nurfuadi, 2008).

\section{KONSEP PENBERDAYAAN}

Pemberdayaan adalah terjemahan dari empowerment. Menurut (Dictionary, 1989) dalam Oxford Engglish Dictionery, kata empower mengandung dua pengertian, yaitu : (1) to give power atau authority to atau memberi kekuasaan, mengalihkan kekuatan atau mengalihkan otoritas ke pihak lain, (2) to give ability to atau enable atau usaha untuk memberi kemampuan (Muttaqin, 2016; Oleh, 2014).

Konsep pemberdayaan lahir sebagai antithesis terhadap model pembangunan yang tidak memihak terhadap rakyat mayoritas (Noor, 2014; Sunandar, 2016). Konsep ini dibangun dari kerangka logic pemusatan kekuasaan dan membuat masyarakat sebagai pekerja yang lemah dan terbentuknya polarisasi masyarakat yang berkuasa dan manusia yang dikuasai. Untuk pembebasan masyarakat dari situasi menguasasi dan dikuasasi, maka harus dilakukan melalui proses pemberdayaan bagi yang dikuasi (Graha, 2009; Nadzir, 2015; Susanti \& Zulaihati, 2017).

Faktor empirik dari kesenjangan sosial yang dikotomis antara yang menguasasi dan dikuasai, melahirkan konsep pemberdayaan (Kurniawati, 2013)dalam dua pandangan; pemberdayaan adalah pawer to nobody atau penghancuran kekuasaan yang telah menghancurkan eksistensi manusia dan terpinggirkan dari keadilan sosial pembangunan, (2) pemberdayaan adalah pembagian kekuasaan kepada setiap orang (pawer to everybody), pemberdayaan adalah penguatan pada yang lemah tanpa menghancurkan yang kuat (Aulia, Mardhiah, Narulita, \& Amanah, 2015).

Menurut Lenin, pemberdayaan masyarakat adalah proses perjuangan kaum powerless untuk memperoleh surplusvalue sebagai hak normatifnya melalui perjuangan distribusi penguasaan melalui politik (Nadzir, 2015). Lain hal dengan Friedman, pemberdayaan harus dimulai dari rumah tangga, bagaimana rumah tangga lemah memperoleh akses informasi, akses pengetahuan dan keterampilan, akses berpartisipasi dalam organisasi sosial dan akses sumbersumber keuangan serta akses berpartisipasi dalam pengambilan keputusan publik yang mempengaruhi masa depan mereka dan juga membangun kepercayaan diri rumah tangga yang lemah (Graha, 2009; Susanti \& Zulaihati, 2017).

Masih banyak pandangan para ilmuan lain tentang pemberdayaan selain 
Leninn, seperti David C. Korten, Uner Kirdar dan Grown, yang pada prinsip bahwa pemberdayaan adalah penguatan masyarakat untuk dapat berpartisipasi dalam proses sosial, ekonomi, politik dan budaya yang akan berpengaruh terhadap masa depan masyarakat itu sendiri (Pranadji, 2016). Dalam proses pembangunan, masyarakat tidak semata menjadi objek pembangunan, akan tetapi sekaligus menjadi sabjek atau pelaku pembangunan itu sendiri. Keterlibatan masyarakat secara partisipatif adalah menjadi faktor utama, sekecil apapun peran masyarakat harus mendapat penghargaan dan tidak ada yang dinapikan sebagai proses usaha partisipatif.

\section{Dakwah Sebagai Agen Perubahan Masyarakat}

Muhammad Iqbal mengatakan bahwa al-Qur'an adalah kitab suci yang mengutamakan amal daripadaidi. Terminologi amal yang menunjuk pada suatu tindakan nyata, empirik dan konkret atas apa yang telah dikonstruksi al-Qur'an secara konseptual. Dengan demikian amal atau karya nyata dalam tradisi Islam menempati peran terpentingdari sisi praktiknya setelah fundamental konseptualnya dibangun sebagaimana tersurat dalam ayat-ayat qauliyah dan qauniyah (Andy Desmawan, 2002).

Dalam kaitannya dengan dakwah Islam, prinsip membangun intelektual umat diharuskan terjun langsung ke lapangan pemikiran dan ke pratik.Sistem antara ilmu dan amal atau semua karya yang mempunyai nilai kebaikan pada dirinya dan orang lain dalam tradisi dakwah akan menjadi perangkat metodis yang kuat apabila diikuti dengan bangunan spiritual yang dalam. Dakwah sesungguhnya tidak sebatas pemberian symbol-simbol ke Islaman, akan tetapi upaya pemberian pemahaman dan pemaknaan dan amal shaleh yang lebih nyata untuk melakukan perubahan kepada masyarakat.

Dakwah sebagai agen perubahan, perbaikan, dan pembaharuan bagi kehidupan manusia yang harus dilakukuan sepanjang zaman yang mampu mengembangkan budaya dan kemanusian (Efendi, 2011).Ruang gerak dakwah sebagai agen perubahan, perbaikan, dan pembaharuan itu cukup luas, yakni ruang keadaan yang dimiliki masyarakat sebagai obyeknya, dengan keadaan yang dicita-citakan dakwah.Oleh karenanya dakwah akan mengidentifikasi masalah-masalah sosial masyarakat yang ada untuk menyusun strategi dan pendekatan yang pas bagaimana perbaikan itu dilakukan secara efektif. Dalam hal ini dakwah akan berfungsi sebagai: (1) I'tiyadi, artinya akan menormalisir yang telah hidup dan berkembang di masyarakat sehingga mempunyai kesadaran religious sesuai dengan tuntan ajaran itu sendiri. (2) Muharriq, artinyamendinamisir yang telah menjdi kesadaran diri manusia sesuai dengan pedoman ajaran Islam. (3) Iqaf, artinya mengadakan verevensi denagn petunjuk, petunjuk dan peringatanperingatan terhadap semua kemungkinan penyakit masyarakat yang tidak dikehendaki agama. (4) Tahrif, rtinya dakwah harus dapat meringankan kesulitan atau penderitaan yang dialami diri dan masyarakat dengan cara kerja dakwah yang tepat (Syafaat, 1992).

Fungsi tersebut di atas akan 
berhadapan langsung dengan kondisi dan situasi diri dan masyarakat yang ada sebagai objek dakwah, pendakwah akan perlu melakukan penilaian mana yang harus untuk dinormalisir saja, mana yang patut untuk didinamisir, dan mana yang perlu prevensi atau yang memerlukan guidance. Dalam hal ini peta dakwah suatu hal keharusan, untuk menentukan sasaran, materi, metode, media dan strategi dakwah yang tepat, agar dakwah bisa melakukan aktivitasnya penuh dengan perhitungan yang matang untuk terlaksananya dakwah yang efektif dan efisien (Dedi, 2017; Sarbini, 2011).

Dalam hal ini penulis menggarisbawahi apa yang dinyatakan oleh (Syafaat, 1992), ada tiga lingkungan yang mejadi sasaran utama dakwah untuk melakukan perubahan: (1) Keluarga, adalah lembaga yang berfungsi sebagai reproduksi, mengembang biakkan manusia sebagai pemberi keturunan, selanjutnya harus bertanggung jawab dalambentuk fungsi pemeliharaan yang harus diselenggarkan demikesejahteraan keluarga. Anak-anak perlu pakaian yang baik, tempat tinggal yang aman dan bersih, makanan yang bergizi dan pendidikan yang sempurna.Lebih jauh suatu keluarga harus memberi arah transmisi pengisian jiwa, pembentukan prilaku luhur dan keyakinan sebagai bekal way of lifeatau jalan hidup yang lurus.Dakwah dalam konteks pewarisan nilai-nilai religious amat penting untuk menciptakan anak yang shaleh bekal mendo'akan ibu-bapaknya dikemudian hari. Warisan orang tua tidak sematamata harta yang ditinggalkan, kata Rasulullah "bahwa apabila seseorang meninggal dunia, akan berakhirlah amal perbuatannya, kecuali tiga hal yakni: petama, anak yang shaleh yang mendo'akan kedua orang tuanya, kedua, sedekah jariyah dan ketiga ilmu yang memberi manfaat bagi orang lain. (2) Dakwah pelayanan formal, ini dapat dilakukan melalui sekolah, pondok pesantren dan sebagainya. Jalur dakwah formal sangat penting terutama bagi generasi muda untuk melakukan pengisian pengetahuan dan keterampilan. Dalam pengertian yang lebih luas sesungguhnya transfer pengetahuan atau pendidikan dan dakwah berlansung sepanjang umur manusia itu sendiri, sebagaimana yang ditekankan Rasul minal mahdi illal lahdi,dari ayunan sampai liang lahat. (3) Dakwah dilingkungan masyarakat luas, mulai dari ligkungan famili yang terdekat, lingkungan kampong halaman, lingkungan kerja dan lingkungan kota dan negara. Tugas dakwah dalam lingkungan ini amat sulit dan peka, karena menyangkut banyak orang, struktur, sosial budaya akan dipermasalahkan.

Tujuan akhir dari segala peruses perubahan, perbaikan dan pembaharuan yang dilakukan dakwah adalah masyarakat dan semua anggotanya memperoleh keuntugan batiniyah dan jasmaniyah, baik untuk kepentingan hidup di dunia maupun diakhirat kelak.Terwujudnya masyarakat yang diridhai Allah SWT, selalu mejadi orientasi dakwah. Lembaga-lembaga pelayanan umum dan pemberdayaan masyarakat sudah selayaknya menjadi perhatian khusus dari kegiatan dakwah (Reza, 2018). Dakwah sebagai agen merubah manusia kearah yang lebih baik, menjamah berbagai aspek kehidupan masyarakat, seperti penyediaan bebagai prasarana fisik bagi kebutuhan hidup masyarakat, da'i sebagai pelaku dakwah harus paham benar tentang kondisi 
masyarakat yang akan menjadi sasaran dakwahnya, baik segi sosial, psychologis, kultural, politik ethnis.

\section{Dakwah Melalui Pendekatan Pemberdayaan.}

Dakwah sebagai agen perubahan yang dihadapkan keberbagai aspek kehidupan umat, tidak bisa diselesaikan dengan pendekatan tabligh semata-mata, dakwah harus dikembangkan kedalam bentuk pemahaman dan tindakan yang lebih makro. Dakwah tidak sebatas proses transpormasi ajaran atau nilai-nilai melalui lisan, akan tetapi proses rekontruksi sosial atau dakwah bil hal dengan berbagai dimensi pendekatan sangat diperlukan sesuai dengan situasi dan kondisi mad'u (Syamsuddin \& Ag, 2016).

Secara garis besarnya ada empat pendekatan dakwah, yakni pertama tabligh dan ta'lim, kedua irsyad, ketiga tathwir, dan keempat tadbir (Muhyiddin \& safei, 2002).Tabligh dilakukan dalam rangka pencerdasan dan pencerahan masyarakat melalui kegiatan sosialisasi, internalisasi nilai ajaran Islam dengan menggunakan sarana mimbar atau media massa. Irsyad dilakukan dalam rangka pemecahan masalah psikologis melalui kegiatan bimbingan penyuluhan pribadi dan bimbingan penyuluhan, keluarga dan kelompok, baik secara preventif maupun kuratif.Tadbir dilakukan dalam rangka perekayasaan sosial dan pemberdayaan masyarakat dalam kehidupan yang lebih baik, peningkatan kualitas sumberdaya manusia (SDM), dan pranata sosial keagamaan, serta menumbuhkan, mengembangkan perekonomian dan kesejahteraan masyarkat dengan penyusunan kebijakan, perencanaan program, pembagian tugas dan pengorganisasian, pelaksanaan dan pemonitoran serta pengevaluasian kegiatan. Tathwir dilakukan melalui pemberdayaan masyarakat dalam rangka peningkatan dan penataan kehidupan sosial budaya masyarakat.

Pemberdayaan masyarakat bertujuan untuk: (1) meningkatkan kemandirian masyarakat dalam mengembangkan kehidupan mereka, (2) meningkatkan kapasitas masyarakat dalam menemukenali dan memprakarsai kegiatan unruk memecahkan permasalahan yang mereka hadapi dengan menggunakan sumber daya (modal keahlian, pengetahuan dan keuangan), mereka sendiri dengan cara berkelanjutan, (3) meningkatkan rasa memiliki dan tanggung jawab masyarkat terhadap kesinambungan kegiatan dan program pembangunan mereka sendiri, dan (4) meningkatkan kapasitas masyarakat dalam menilai sumber daya yang bisa mendukung kegiatan mereka (Sahabuddin, 2016).

Al-Qur'an sebagai sumber dasar dakwah memberikan petunjuk dalam proses transformasi sosial masyarakat (Muttaqin, 2016). Nabi Muhammad Saw. Sebagai penerima wahyu dalam awal pengalaman kenabiannya, ia berhadapan dengan ketidak harmonisan hubungan antara manusia dengan manusia, manusia dengan alam,dan manusia dengan Tuhannya. Ketiga hal ini, manusia menjadi titik sentral munculnya problematik sosial.Oleh karena itu tindakan meditasi yang dilakukan Nabi Muhammad di gua hira sebagai refleksi terhadap realitas yang dihadapi saat itu.

Problem kemanusiaan yang mengarah pada dehumanisasi dan ketidak 
berdayaan umat manusia untuk berpikir kritis, maka Allah menurunkan al-Qur'an dengan sasaran utama manusia sebagaimana yang tertera dalam alQur'an Surat al-A'laq:

"Bacalah dengan nama Tuhan-mu yang menciptakan, (2) Dia menciptakan manusia dari sengumpal darah, (3) Bacalah, dan Tuhan-mu adalah, dan Tuhan-mu adalah Yang Maha Pemurah, (4) yang mengajari manusia dengan perantaraan qalam, dan (5) Dia mengajari manusia apa yang tidak diketahui"(6) Ketahuilah, sesungguhnya manusia benar-benar melanggar batas, (7) karena dia melihat dirinya serba bias, dan (8) sesungguhnya hanya kepada Tuhan-mu semua kembali.

Ayat tersebut di atas secara eksplisit tidak berbicara pada dimensi ke-Tuhanan, akan tetapi berbicara pada dimensi kemanusiaan dalam proses pemberdayaan dan penyadaran manusia lebih manusiawi dan menemukan dirinya sendiri. Kalau merujuk apa yang dicontohkan Rasulullah Saw.ketika membangun masyarakat ada tiga tangga proses, yakni, takwin, tanzin, taudi.Takwinadalah tahap pembentukan masyarakat Islamdengan dakwah bil lisan sebagai sosialisasi aqidah, ukhwah dan ta'awun. Proses ini dimulai dari diri sendiri, keluarga, sahabat terdekat dan masyarakat luas. Dengan pendekatan ini terjadinya internalisasi Islam dalam kepribadian setiap individu dan mayarakat.

Menurut (Ahmad, 1999), pada tahap takwin, fundamental sosial Islam dalam bentuk akidah, ukhwah Islamiyah, ta'wun dan shalat telah dijalankan oleh Nabi. Tauhid telah menjadi instrument sosiologis dalam mempersatukan para sahabat'dan masyarakat muslim yang sangat mendalam (Muhyiddin \& safei, 2002). Tahap berikutnya tanzim, yakni tahap pembinaan dan penataan masyarakat. Pada pase ini internalisasi dan eksternalisasi Islam muncul dalam bentuk institusionalisasi Islam secara komprehensif dalam realitas sosial.

Pada pase sekarang yang sering disebut pase masyarakat madani problem dakwah seharusnya tidak lagi sematasemata bertumpu pada persoalanpersoalan tauhid dan fiqhi semata. Menurut (Mulkhan, 1994, 2005; Nida, 2016) problem agama yang sekali gus problem dakwah merupakan pembebasan manusia dan dunia dari kemiskinan, konflik etnis, penindasan atas nama Negara, idiologi politik,dan bahkan atas nama agama. Oleh karena itu, agama dan dakwah harus dipahami sebagai wacana kebudayaan, karena ketika disentuh oleh pemikiran manusia, wahyu Allah akan berubah menjadi masalah kebudayaan. Ketika praktik agama dan dakwah berlebihan dalam mengurusi hal-hal yang bersifat fighiyah, bid'ah dan dhalalah dakwah cenderung tidak memperhatikan hal-hal yang bersifat manusiawi dan tidak peduli terhadap berbagai persoalan konkret yang dihadapi masyarakat.

Tanpa kesedian menjadikan agama dan dakwah sebagai wacana budaya (terbelenggu dalam pimikiran normatif), Menurut Mulkhan upaya dakwah dalam membangun serta pengembangan masyarkat mengalami kesulitan untuk secara sungguh-sungguh peduli terhadap penderitaan dan kemiskinan.Oleh karena itu konsep dan strategi dakwah harus diarahkan pada pemecahan berbagai persoalan yang dihadapi masyarakat di lapangan (Jamalie, 2015).Strategi dakwah semacam ini paling tidak bisa 
menumbuhkan kemendirian masyarakat serta kepercaan terhadap kegiatan dakwah untuk mencapai kehidupan yang lebih secara dunia dan ukhrawi serta terbangunnya sosio-kultural masyarakat yang Islami.

Dengan demikian, pemecahan masalah melalui dakwah atau pemberdayaan masyarakat merupakan upaya yang demokratis bagi pengembangan dan peningkatan kualitas hidup sebagai bagian pemberdayaan masyarakat dalam menyelesaikan berbagai persoalan kehidupan objektif. Komunitas masyarakat muslim terkecil sekalipun dapat dikembangkan menjadi komunitas sosial yang mempunyai kemampuan internalmandiri dalam menyelesaikan berbagai persoalan yang dihadapinya.

Secara metodologis langkah-langkah melakukan perubahan dengan pendekatan pemberdayaan dapat dilakukan denganta'aruf, tafahum, tasyaur, ta'awun, taghyir, adalah dan mashlahah Mursalah (Abdullah Faisol, 2005). Ta'aruf, mengenali masyarakat sebagai proses`penyesuaian diri.Perbedaan status sosial kadangkala membuat jarak sosial sehingga menimbulkan keterputusan dan keterasingan satu dengan yang lainnya.Penerimaan seseorang di tengahtengah masyarakat didasarkan kepada persamaan sehingga komunikasi dialogis dapat terjalin dengan baik. Tafahum, memahami struktur sosial masyarakat sebagai proses menganalisis problem sosial yang terjadi. Tasyaur, melakukan perembukan atau musyawarah bersama masyarakat, dengan menghilangkan struktur sosial untuk memecahakan persoalan yang sedang dihadapi.Hasil yang dicapai merupakan hasil kerja kolektif

bukan

dominasi

perorangan.Ta'awun, Kerjasama atau kolaborasi dalam rangkaian melakukan tindakan atau aksi positif.Taghyir, melakukan perubahan secara bertahap dari kelompok kecil kepada kelompok besar dari ketertutupan kepada keterbukaan.Adalah, Keadilan sosial dalam bentuk keberpihakkan kepada yang lemah atau yang terpinggirkan oleh system pembangunan yang tidak berpihak kepada pihak yang lemah kelompok "mustadh'afin". Mashlahah Mursalah, proses transpormasi pembangunan harus menciptakan kesejahteraan umum, menyadarkan masyarakat untuk berbuat, menghilangkan belenggu keadilan sosial untuk mencapai pencerahan dan pembebasan.

Bagaimana proses melakukan perubahan dari tradisi yang tidak baik kepada yang baik Allah telah memberi pelajaran lewat petunjuknya sebagaimana yang dilakukan oleh Rasulullah menurut petunjuk wahyu terhadap menghentikan tradisi mengkomsumsi minuman keras. Pertama, Al-Qur'an menawarkan minuman alternative dengan susu dengan mengajak berpikir untuk memperbandingkan nilai manfaat dan mudaratnya. Kedua, ketika mereka melakukan shalat dan diantara mereka ditunjuk sebagai Imam, lalu keliru membaca ayat akibat pengaruh minuman beralkohol itu,Al-qur'an melarang mereka agar tidak melakukan shalat ketika berada dalam pengaruh alkohol. Ketiga, ketika larangan lokalisasi minuman keras itu ketika terbatas menjelang melaksanakan shalat membuat mereka tidak jera dan berhenti, mereka tetap mengkomsumsi setelah selesai shalat isya di malam hari supaya lebih leluasa, maka akhirnya 
secara responsif Al-qur'an melarangnya secara total.

\section{KESIMPULAN}

Munurut pandangan dakwah, masyarakat sebagai objek dakwah adalah kumpulan manusia yang dapat dibangun kemanusiaannya melalui pemahaman, dan penyadaran secara religious dengan progresif terhadap struktur sosialnya, karena manusia bukan benda mati sebagaimana halnya dalam kacamata sosial positivism, akan tetapi manusia dapat merubah dirinya sendiri melalui pranata-pranata dakwah yang diciptakan sendiri. Konsep dakwah dalam membangun kesadaran dan penyadaran manusia untuk merubah nasibnya sendiri tidak boleh dipaksakan dari sesuatu yang datang diluar dirinya. Akan tetapi teknik pasilitasi dengan memberi dorongan dan penggalian serta memanfaatkan potensi kesadaran dirinya akan lebih ampuh. Oleh karena itu, Allah melarang memaksa orang lain masuk Islam, tanpa dibaringi dengan proses kesadaran dari dirinya sendiri, proses ini yang dinamakan dengan pendekatan pemberdayaan masyarakat dakwah.

\section{REFERENSI}

Ahmad, A. (1999). Dakwah Islam Sebagai Ilmu: Sebuah Kajian Epistemologi dan Struktur Keilmuan Dakwah. Medan: Makalah.

Abdullah Faishol, dkk. 2005. Metode dan Teknik Kuliah Kerja Nyata Transformatif. Surakarta: P3M STAIN: 2005

Aini, D. N. (2018). Pengaruh pesan dakwah Hj. Mahfudhoh terhadap akhlak bertetangga ibu-ibu Jama'ah Tahlil Masjid Al-Mustofa Desa Ngunut Kec. Dander Kab. Bojonegoro (PhD Thesis). UIN Sunan Ampel Surabaya.

Akmal, R., \& ACEH, B. (2017). Efektivitas Program Dakwah Ma'had UIN ArRaniry dalam Meningkatkan Kesadaran Beragama Mahasiswa". (PhD Thesis). Perpustakaan.

Andy Demawan. 2002. Strategi Dakwah Islam dalam Pendekatan Rasional dan Tradisional. Al Jami'ah, Volume 40(1)

Aulia, R. N., Mardhiah, I., Narulita, S., \& Amanah, N. (2015). Pemberdayaan Ekonomi Komunitas Muslim Melalui Bank Sampah. Jurnal Studi Al-Qur'an, 11(2), 102-113.

Budiantoro, W. (2017). Dakwah di Era Digital. KOMUNIKA: Jurnal Dakwah Dan Komunikasi, 11(2), 263-281.

Dedi, P. (2017). Strategi Dakwah Remaja Masjid Al-Wustho, Di Dukuh Mendungsari Bulurejo, Gondangrejo, Karanganyar. (PhD Thesis). IAIN Surakarta.

Dictionary, O. E. (1989). Oxford english dictionary. Simpson, JA \& Weiner, ESC.

Efendi, A. (2011). Manajemen perubahan di lembaga dakwah: studi kasus tentang pengembangan organisasi di lembaga Griya Al-Qur'an Surabaya (PhD Thesis). IAIN Sunan Ampel Surabaya. 
Fatmawati, F. (2018). Analisis Framing Pesan Kesalehan Sosial Pada Buku Ungkapan Hikmah Karya Komaruddin Hidayat. Al-Balagh: Jurnal Dakwah Dan Komunikasi, 3(1), 73-102.

Graha, A. N. (2009). Pengembangan Masyarakat Pembangunan Melalui Pendampingan Sosial dalam Konsep Pemberdayaan di Bidang Ekonomi. Jurnal Ekonomi Modernisasi, 5(2), 117-126.

Hakim, M. (2016). Ukhwah Islamiyah dalam film Sajadah Ka'bah (PhD Thesis). UIN Walisongo.

Hasanah, U. (2014). Keberadaan Kelompok Jamaah Tabligh dan Reaksi Masyarakat (Perspektif Teori Penyebaran Informasi dan Pengaruh). Jurnal Indo-Islamika, 4(1), 21-44.

Hidayat, A. S. (2013). Membangun Dimensi Baru Dakwah Islam: Dari Dakwah Tekstual menuju Dakwah Kontekstual. Jurnal Dakwah Risalah, 24(2), 1-15.

HIKMAWATI, N. (2016). Model Pembinaan Lembaga Dakwah Kampus dalam Menanggulangi Perilaku Menyimpang Mahasiswa IAIN Kendari (PhD Thesis). IAIN KendarI.

Ismail, I., \& Hotman, P. (2013). Filsafat Dakwah Rekayasa Membangun Agama dan Peradaban Islam. Kencana.

Jamalie, Z. (2015). Pola Dakwah Pada'Masyarakat Suku Terasing'Di Kalimantan Selatan. Jurnal Dakwah, 16(1), 1-18.
Kurniawati, D. P. (2013). Pemberdayaan masyarakat di bidang usaha ekonomi (studi pada Badan Pemberdayaan Masyarakat kota Mojokerto). Jurnal Administrasi Publik, 1(4), 9-14.

Muhyiddin, D. H. A., \& safei, A. A. (2002). Metode Pengembangan Dakwah. CV. Pustaka Setia Bandung.

Mulkhan, A. M. (1994). Runtuhnya mitos politik santri: strategi kebudayaan dalam dakwah Islam. Sipress.

Mulkhan, A. M. (2005). Kesalehan multikultural: ber-Islam secara autentik-kontekstual di aras peradaban global. Pusat Studi Agama dan Peradaban Muhammadiyah.

Muttaqin, R. (2016). Kemandirian dan pemberdayaan ekonomi berbasis pesantren (studi atas peran Pondok Pesantren Al-ittifaq Kecamatan Rancabali Kabupaten Bandung terhadap kemandirian eknomi santri dan pemberdayaan ekonomi masyarakat sekitarnya). JESI (Jurnal Ekonomi Syariah Indonesia), 1(2), 65-94.

Nadzir, M. (2015). Membangun Pemberdayaan Ekonomi Di Pesantren. Economica: Jurnal Ekonomi Islam, 6(1), 37-56.

Nida, F. L. K. (2016). Mengembangkan Dakwah Humanis Melalui Penguatan Manajemen Organisasi Dakwah. TADBIR: Jurnal Manajemen Dakwah, 1(2). 
Noor, M. (2014). Penanggulangan Kemiskinan di Indonesia (Studi Tentang Program Nasional Pemberdayaan Masyarakat Mandiri Perkotaan Di Kota Semarang). Serat Acitya, 3(1), 130.

Nurfuadi, N. (2008). Reaktualisasi Profesi Dakwah. KOMUNIKA: Jurnal Dakwah Dan Komunikasi, 2(1), 5472.

Oleh, H. F. (2014). Pelaksanaan Kebijakan Alokasi Dana Desa (ADD) dalam Memberdayakan Masyarakat Desa di Desa Cerme, Kecamatan Grogol, Kabupaten Kediri. Jurnal Kebijakan Dan Manajemen Publik, 2(1).

Pranadji, T. (2016). Penguatan Modal Sosial Untuk Pemberdayaan Masyarakat Pedesaan dalam Pengelolaan Agroekosistem Lahan Kering (Studi Kasus di Desa-desa (Hulu DAS) Ex Proyek Bangun Desa, Kabupaten Gunungkidul dan Ex Proyek Pertanian Lahan Kering, Kabupaten Boyolali).

Restendy, M. S. (2017). Dakwah virtual Lembaga Spirit Dakwah Indonesia (SPIDI) Tulungagung (PhD Thesis). UIN Sunan Ampel Surabaya.

REZA, M. (2018). Nilai-Nilai Dakwah Bil Hal dalam Program Pendistribusian Zakat (Studi di BAZNAS Kota Serang) (PhD Thesis). Universitas Islam Negeri" Sultan Maulana Hasanuddin" Banten.

Riyadi, A. (2014). Formulasi Model Dakwah Pengembangan Masyarakat Islam. An-Nida: Jurnal Komunikasi Islam, 6(2).
Safei, H. A. A. (2016). Sosiologi Dakwah Rekonsepsi, Revitalisasi, dan Inovasi. Deepublish.

Sahabuddin, E. S. (2016). Pengelolaan Lingkungan Diutamakan Sebagai Pengelolaan Manusia (Berbasis Masyarakat) dan Segala Aksesnya Pada Lingkungan Hidup.

Sarbini, A. (2011). Dakwah Berbasis Budaya Lokal: Studi tentang Model-model Dakwah di Jawa Barat. Ilmu Dakwah: Academic Journal for Homiletic Studies, 5(17), 291-322.

Shobron, S., Rosyadi, I., \& Suaidy, M. Z. (2016). Dakwah Bil-HÂl Pesantren Walisongo Ngabar Ponorogo Jawa Timur Dalam Pemberdayaan Ekonomi Masyarakat Tahun 20132014. Profetika: Jurnal Studi Islam, 16(1), 1-24.

Sunandar, D. M. (2016). Kajian Implementasi Bauran Pemasaran Kepariwisataan Dalam Upaya Peningkatan Kunjungan Wisata Dan Implikasinya Terhadap Pendapatan Asli Daerah Dan Pemberdayaan Ekonomi Masyarakat (Studi di Pantai Wisata Pangandaran Jawa Barat) Study Of Implementation Of The Marketing Mix of Tourism In An Effort To Develop Tourism and Its Implications To Increase Local Revenue and Economic Empowerment (Study On Pangandaran Beach Tourism-West Java) (PhD Thesis). UNPAS. 
Susanti, S., \& Zulaihati, S. (2017). Penyuluhan Gizi Dan Pemberdayaan Ekonomi Perempuan Kelurahan Sindang Barang Bogor. Jurnal Pemberdayaan Masyarakat Madani (JPMM), 1(1), 73-85.

Syafaat, H. M. (1992). Buku Pedoman Dakwah. PT Wijaya, Jakarta.

Syamsuddin, A. B., \& Ag, S. (2016). Pengantar Sosiologi Dakwah. Kencana.

Thoyyib, A. S. M. S., Fahmi, M., \& Si, M. (2018). Media Dakwah Komunitas Indonesia Syiar Network Solo (ISN) (PhD Thesis). IAIN Surakarta.
Utami, A. M. (n.d.). Analisis isi pesan dakwah dalam novel diorama sepasangal-banna karya ari nur.

Yasiroh, F. (2016). Analisis programming acara religi "Ngaji Bareng NU" di Simpang5 TV Pati (PhD Thesis). UIN Walisongo.

Zainudin, Z. (2009). Dakwah Rahmatan Lil-'Alamin: Kajian tentang Toleransi Agama dalam Surat AlKafirun. Jurnal Dakwah, 10(1), 1931. 
78 || Turast: Jurnal Penelitian dan Pengabdian Vol. 6, No. 1, Januari-Juli 2018 
